\title{
Sex differences among recipients of benzodiazepines in Dutch general practice
}

\author{
Fransje W van der Waals, Jacob Mohrs, Marleen Foets
}

\section{Abstract}

Objective-To analyse sex differences among recipients of benzodiazepines in Dutch general practice.

Design-Study of consultations and associated interventions as recorded in the Dutch national survey of general practice.

Setting-Practices of 45 general practitioners monitored during 1 April to 30 June 1987.

Subjects-61 249 patients $(29035(47 \cdot 4 \%)$ men in the age groups 19-44, 45-64, and 65 years and over.

Main outcome measures-Symptoms among recipients of repeat as well as new benzodiazepine prescriptions stratified by sex and age.

Results-Prescriptions for benzodiazepines were found to be significantly more common among women than among men, $(a)$ after correcting for the sex distribution of the total patient population, and (b) in the two oldest age groups after correcting for the number of consultations. Of all prescriptions for benzodiazepines, $89 \%(6055 / 6777)$ were repeats and $70 \%(4759 / 6777)$ requests. Only $9 \%(439 / 4759)$ of these were authorised by the general practitioner, the rest being issued by the general practitioner's assistant after he or she had referred to the diagnosis in the patient's record. In contrast, only three $(1 \%)$ of the $\mathbf{4 9 2}$ first time recipients of benzodiazepines had requested a prescription and were not seen by the general practitioner. Women $(43 / 96 ; 45 \%)$ aged $45-64$ years received their first prescription for benzodiazepines almost twice as often as men $(15 / 63 ; 24 \%)$ without symptoms or a diagnosis being an indication (female to male relative risk $1.88(95 \%$ confidence interval $1 \cdot 15$ to $3 \cdot 08$ )).

Conclusions-The sex difference among first time recipients of benzodiazepines seems to be due to general practitioners being less stringent when prescribing this drug for women. The difference continues in repeat prescriptions, physicians failing to check adequately the need for these.

\section{Introduction}

In the Netherlands, as in the United States and the rest of Europe, some $10 \%$ of the population use tranquillisers and hypnotics. ${ }^{1-7}$ In 1989 roughly one third of Dutch patients had been taking tranquillisers or hypnotics, mostly benzodiazepines, continually for 180 days or longer and were designated long term users. ${ }^{3}$ Most long term users of benzodiazepines in the United States and Europe are elderly women. ${ }^{813}$ National household surveys on the use of tranquillisers and hypnotics in the Netherlands in 1985 and 1989 disclosed that women in the age group 15-44 used these drugs at about the same low frequency $(2 \%)$ as did men. ${ }^{67}$ At ages 45-64 years and 65 and over, however, $10 \%$ and $16 \%$ of the women respectively used tranquillisers or hypnotics in 1985; in the older age group this figure increased to $18 \%$ in 1989 . These figures contrasted sharply with those for men; in two older age groups only $6 \%$ and $9 \%$ of men used these drugs.

Benzodiazepines are mainly prescribed by general practitioners. ${ }^{14}{ }^{15}$ After drugs for heart and circulatory problems benzodiazepines are the drugs most frequently prescribed by Dutch general practitioners. ${ }^{16}$ Exact figures on the use of benzodiazepines and the reasons for prescription are not available as there is no central register of medication and consumption. Most assessments come from doctor-patient registrations, ${ }^{15}$ health surveys, ${ }^{51617}$ pharmacy records, ${ }^{18}$ and the Dutch national health service. ${ }^{19}$

Recently a national survey of general practice was conducted in the Netherlands. ${ }^{20}$ It included the complete records of all consultations with 161 representative general practitioners and their assistants during 1 April 1987 to 31 March 1988 . That study enabled us to analyse the circumstances of the initial and repeat prescriptions for benzodiazepines. Firstly, we investigated whether the figures on the use of benzodiazepines gathered from the national survey of general practice paralleled the figures from the national household surveys. Secondly, we tried to discover why doctors prescribe benzodiazepines more to women than to men.

\section{Subjects and methods}

DESIGN OF NATIONAL SURVEY OF GENERAL PRACTICE General practitioner sampling

From all 5826 general practitioners in the Netherlands on 1 Janaury 1985 a random, stratified, nonproportional sample was selected. Stratification was deemed necessary because of geographic factors contributing to morbidity data and procedures in general practice. The country was divided into three regions and four levels of urbanisation. Finally, the distance from the doctor's practice to a hospital was noted.

Comparison of the total general practitioner population in the Netherlands with the 161 doctors selected showed that $24(15 \%)$ of the sample group but only 466 $(8 \%)$ of all general practitioners were women. In addition, the sample group was younger and included a larger proportion of doctors in group practices.

We studied the practices of the $\mathbf{4 5}$ general practitioners for whom during the first three month period (1 April to 30 June 1987) details of all repeat prescriptions were recorded.

\section{Doctor-patient contacts}

Contacts with the general practitioner were recorded during consecutive three month periods of the survey year. A full registration form was used for contacts with the doctor and a shorter version of the form for contacts with the assistant to the general practitioner. No significant differences were found in regional
Correspondence to:

$B M \Im$ 1993;307:363-6 
distribution, urbanisation, or distance to the hospital between the first group of doctors (our study group) and doctors in the other three groups. Also other variables such as characteristics of the practices, numbers of episodes, reasons for consultations, sex distribution of the patients, and types of health insurance did not differ. Seasonal influences on the data were minimal.

The contact registration form included the general practitioner's identification code; the patient's identification code; the description of contact (first consultation, repeat consultation, relapse); morbidity data (reasons for consultation (reported as symptoms and diagnosis)); intervention data; and, finally, prescription data. We used records of first and repeat consultations, symptoms, diagnosis, and subsequent new or repeat prescriptions. These variables were recorded by the general practitioner and his or her assistant. For each general practitioner one fieldworker was appointed to be responsible for recording, classifying, and coding data. This centralised procedure resulted in an interobserver agreement score of 0.85 for reasons for consultation and 0.80 for rare or complicated diagnoses. The symptoms and diagnoses were classified according to the International Classification of Primary Care, ${ }^{21}$ with some minor changes. ${ }^{22}$

\section{Patient registration}

The 45 general practitioners cared for a total of 61249 patients. Their age and sex distribution did not differ significantly from that of the population as a whole. A patient registration form including information on socioeconomic status, was completed by $91 \%$ of the study population.

\section{Benzodiazepine prescriptions}

We selected for our study the following symptoms and diagnoses recorded in the International Classification of Primary care as indications for benzodiazepine: anxiety or nervousness or feelings of inadequacy, or both; acute stress or panic disorders, or both; irritability or anger, or both; restlessness or agitation, or both; insomnia. As an additional category we studied requests for a prescription or repeat prescription.

TABLE I-Numbers (percentages) of patients in general practice population prescribed benzodiazepines

\begin{tabular}{lccc}
\hline $\begin{array}{l}\text { Age group } \\
\text { (years) }\end{array}$ & No (\%) of total patient population prescribed benzodiazepines & & $\begin{array}{c}\text { Female to male relative risk } \\
\text { (95\% confidence interval) }\end{array}$ \\
\cline { 2 - 3 } & Women & Men & $1.68(1.48$ to $1 \cdot 89)$ \\
$19-44$ & $695 / 18065(4)$ & $393 / 17112(2)$ & $1.92(1.73$ to $2 \cdot 13)$ \\
$45-64$ & $997 / 8172(12)$ & $501 / 7879(6)$ & $1.91(1.73$ to $2 \cdot 12)$ \\
\hline 65 & $1215 / 5977(20)$ & $430 / 4044(11)$ & \\
\hline
\end{tabular}

TABLE II-Numbers (percentages) of patients visiting general practitioners who were prescribed benzodiazepines

\begin{tabular}{lccc}
\hline & \multicolumn{2}{c}{$\begin{array}{c}\text { No (\%) of general practitioner consulting patient population } \\
\text { prescribed benzodiazepines }\end{array}$} & $\begin{array}{c}\text { Female to male relative risk } \\
\text { (95\% confidence interval) }\end{array}$ \\
\cline { 2 - 3 } $\begin{array}{l}\text { Age group } \\
\text { (years) }\end{array}$ & Women & Men & $1 \cdot 13(1.00$ to $1 \cdot 27)$ \\
& & $393 / 7306(5)$ & $1.57(1.42$ to $1 \cdot 74)$ \\
$19-44$ & $695 / 11456(6)$ & $501 / 4267(12)$ & $1.67(1.51$ to $1 \cdot 84)$ \\
$45-64$ & $997 / 5399(18)$ & $430 / 2827(15)$ & \\
\hline
\end{tabular}

\section{Computer analysis and statistics}

We evaluated prescriptions in relation to reasons for consultation (reported as symptoms and diagnoses) stratified by sex and age. The SPSS package was used to compute the risks and $95 \%$ confidence intervals. In this study the relative risk ratio is the same as the female to male relative risk ratio.

\section{Results}

AGE AND SEX DISTRIBUTION OF BENZODIAZEPINE RECIPIENTS

The 61249 patients in the study population comprised 29035 men and 32214 women. Analysis of the frequency of consultations with the general practitioner showed that 36047 patients (14400 male, 21647 female) visited their general practitioner at least once during the three months.

Benzodiazepines were prescribed at least once to 4231 patients (1324 (31\%) male, 2907 (69\%) female). The numbers of patients prescribed benzodiazepines increased with age among both men and women (table I). In the older age groups (45-64 and 65 and over) the absolute increase was greater for women (from $12 \%$ to $20 \%$ ) than for men (from $6 \%$ to $11 \%$ ). Even after correcting for sex distribution in the total patient population significantly more women than men were recorded as receiving benzodiazepine prescriptions (relative risk 1.68-1.92).

When we corrected for the sex difference in visits to the general practitioner significantly more women (relative risk 1.57 for the age group 45-64 years, 1.67 for age 65 and over) than men were prescribed benzodiazepines (table II).

\section{INDICATIONS FOR CONTINUING BENZODIAZEPINES} ASSESSED BY GENERAL PRACTITIONER

A total of $1448(69 \%)$ male patients and $3311(71 \%)$ female patients received a prescription for benzodiazepines on request. Because most patients' contacts with the practice entailed a request $(4759(70 \%))$ for benzodiazepines or a repeat $(6055(89 \%))$ prescription we decided to study to what extent general practitioners reassessed their patients' needs for repeat prescriptions.

In $90 \%$ of the men requesting benzodiazepines and $91 \%$ of the women the prescriptions were issued by the general practitioner's assistant, who referred to the diagnosis in the patient's record. These proportions were significantly higher than those in contacts with assistants that resulted in non-benzodiazepine prescriptions (data not shown).

We studied visits to the practice by benzodiazepine recipients for reasons unrelated to benzodiazepines. Most of these patients were seen by the general practitioner. No significant differences between men and women were observed.

Given that most benzodiazepine prescriptions were issued by the assistant and not by the general practitioner, the correlation among symptoms, diagnosis, and actual prescriptions was remarkably good in all age groups. No differences between men and women were observed. Between $73 \%$ and $85 \%$ of all symptoms considered indications for benzodiazepines were diagnosed as such. Also between $65 \%$ and $85 \%$ of all

TABLE III-Numbers (percentages) of patients initially prescribed benzodiazepines for symptoms and diagnoses

\begin{tabular}{|c|c|c|c|c|c|c|}
\hline \multirow[b]{2}{*}{$\begin{array}{l}\text { Age group } \\
\text { (years) }\end{array}$} & \multicolumn{3}{|c|}{ Patients given benzodiazepines for symptoms } & \multicolumn{3}{|c|}{ Patients given benzodiazepines for diagnoses } \\
\hline & $\begin{array}{l}\text { No }(\%) \text { of } \\
\text { women }\end{array}$ & $\begin{array}{c}\text { No }(\%) \text { of } \\
\text { men }\end{array}$ & $\begin{array}{l}\text { Female to male relative risk } \\
(95 \% \text { confidence interval })\end{array}$ & $\begin{array}{l}\text { No }(\%) \text { of } \\
\text { women }\end{array}$ & $\begin{array}{l}\text { No }(\%) \text { of } \\
\text { men }\end{array}$ & $\begin{array}{l}\text { Female to male relative risk } \\
(95 \% \text { confidence interval) }\end{array}$ \\
\hline $19-44$ & $73 / 149(49)$ & $46 / 89(52)$ & $0.95(0.73$ to 1.23$)$ & $89 / 249(60)$ & $61 / 89(69)$ & $0.87(0.72$ to 1.06$)$ \\
\hline $45-64$ & $45 / 96(47)$ & $41 / 63(65)$ & $0.72(0.54$ to 0.95$)$ & $56 / 96(58)$ & $43 / 63(68)$ & $0.85(0.67$ to 1.08$)$ \\
\hline$\geqslant 65$ & $31 / 70(44)$ & $13 / 25(52)$ & $0.85(0.85$ to 1.35$)$ & $34 / 70(49)$ & $13 / 25(52)$ & $0.93(0.60$ to 1.46$)$ \\
\hline
\end{tabular}




\begin{tabular}{|c|c|c|c|c|c|c|}
\hline \multirow[b]{2}{*}{$\begin{array}{l}\text { Age group } \\
\text { (years) }\end{array}$} & \multicolumn{3}{|c|}{ Patients with symptoms as proportion of all incident diagnoses } & \multicolumn{3}{|c|}{ Patients without symptoms as proportions of all incident diagnoses } \\
\hline & $\begin{array}{l}\text { No }(\%) \text { of } \\
\text { women }\end{array}$ & $\begin{array}{l}\text { No (\%) of } \\
\text { men }\end{array}$ & $\begin{array}{l}\text { Female to male relative risk } \\
(95 \% \text { confidence interval) }\end{array}$ & $\begin{array}{l}\text { No }(\%) \text { of } \\
\text { women }\end{array}$ & $\begin{array}{l}\text { No (\%) of } \\
\text { men }\end{array}$ & $\begin{array}{l}\text { Female to male relative risk } \\
(95 \% \text { confidence interval })\end{array}$ \\
\hline $19-44$ & $42 / 89(47)$ & $33 / 61(54)$ & $0.87(0.63$ to 1.20$)$ & $47 / 89(53)$ & $28 / 61(46)$ & $1.15(0.82$ to 1.61$)$ \\
\hline $45-64$ & $28 / 56(50)$ & $28 / 43(65)$ & $0.77(0.55$ to 1.08$)$ & $28 / 56(50)$ & $15 / 43(35)$ & $1.43(0.88$ to 2.33$)$ \\
\hline$\geqslant 65$ & $20 / 34(59)$ & $7 / 13(54)$ & $1.09(0.61$ to 1.94$)$ & $14 / 34(41)$ & $6 / 13(46)$ & $0.89(0.44$ to 1.82$)$ \\
\hline
\end{tabular}

prescriptions for benzodiazepines were backed by a relevant diagnosis.

INITIAL BENZODIAZEPINE PRESCRIPTIONS AND SEX DIFFERENCES IN SYMPTOMS AND DIAGNOSES

As only $32 \%$ of benzodiazepine prescriptions $(2166 / 6777)$ were written by the general practitioner it was difficult to study the doctor-patient interaction in long term users. We therefore studied 492 incident cases-that is, prescriptions that were annotated as "new" prescriptions separately. Of these patients, 489 $(99 \%)$ were seen by the general practitioner. In contrast with $79 \%$ of repeats of all benzodiazepine prescriptions that were requests $(4756 / 6055)$, among the 492 incident cases only three $(1 \%)$ requests for benzodiazepines were recorded. The high frequency of contacts with general practitioners allowed us to study the impact of doctor-patient interactions on new benzodiazepine prescriptions (table III). In all age groups more men than women had symptoms classified as indications for benzodiazepines. In the age group $45-64$ years the difference was $65 \% v 47 \%$. Likewise, doctors diagnosed more in men than in women a condition requiring benzodiazepines, particularly at ages 45-64 years.

We also compared diagnoses based on symptoms considered to be indications for benzodiazepines with diagnoses made without symptoms (table IV). In the youngest age group (19-44 years) and in the oldest age group (65 and over) about half of the diagnoses were made in patients without relevant symptoms. No significant differences were observed between men and women. In the age group 45-64 years diagnoses warranting benzodiazepines were made less frequently in women. This difference did not, however, reach statistical significance. Surprisingly, benzodiazepines were prescribed to men for headache, general malaise and fatigue, chest pain, and sensory disturbances and to women for general malaise and fatigue, vertigo, depression and headache, and chest pain.

Table $\mathrm{V}$ shows the frequency with which doctors prescribed benzodiazepines when no symptoms were identified or a diagnosis made warranting the treatment. A significant difference was observed in the age group 45-64. Women in this group received benzodiazepines without indication almost twice as often as men $-45 \%$ of women $(43 / 96) v 24 \%$ of men $(15 / 63)$.

In men of all age groups the most frequent symptoms were back pain, accident trauma, headache, sensory disturbances, and non-specified pain. The most frequent diagnoses in men were lumbago, alcohol misuse, myalgia, problems at work, and problems resulting from the death of a family member (other than a child or partner). In women the most frequent symptoms were headache, chest pain, general malaise

TABLE $\mathrm{v}-$ Numbers (percentages) of patients initially prescribed benzodiazepines without any indication for their use, based on symptoms or diagnosis

\begin{tabular}{|c|c|c|c|}
\hline \multirow{2}{*}{$\begin{array}{l}\text { Age group } \\
\text { (years) }\end{array}$} & \multicolumn{2}{|c|}{ No $(\%)$ of patients } & \multirow{2}{*}{$\begin{array}{l}\text { Female to male relative risk } \\
(95 \% \text { confidence interval })\end{array}$} \\
\hline & Women & Men & \\
\hline $19-44$ & $58 / 149(39)$ & $32 / 89(36)$ & $1.08(0.77$ to 1.52$)$ \\
\hline $45-64$ & $43 / 96(45)$ & $15 / 63(24)$ & $1.88(1.15$ to 3.08$)$ \\
\hline$\geqslant 65$ & $39 / 70(56)$ & $12 / 25(48)$ & $1.16(0.73$ to 1.84$)$ \\
\hline
\end{tabular}

and fatigue, abdominal pain, palpitations, back pain, and diarrhoea. The most frequent diagnoses in women were headache, hypertension, family problems, back pain, myalgia, cystitis, and problems resulting from the death of a partner.

Though lumbago and back pain might be considered legitimate reasons to prescribe benzodiazepines, we did not include these symptoms or diagnoses in our study; muscle relaxation is not mentioned in efficacy studies as an indication for the drug. When women with back pain $(9 / 315 ; 3 \%)$ and men with lumbago $(18 / 177 ; 10 \%)$ were excluded the difference between women and men was even greater-132 $(42 \%)$ of the women and $25(14 \%)$ of the men received benzodiazepines without having relevant symptoms or diagnoses.

\section{Discussion}

Our general practice survey, confirming the results of other studies, showed that women are more often prescribed benzodiazepines than men. ${ }^{22}{ }^{23}$ The results of our analysis agree exactly with the results of the Dutch national household surveys, in which respondents reported their use of benzodiazepines. ${ }^{89}$ In all age groups, but particularly in the older age groups far more women received benzodiazepines than did men. This was true even after correction for the female to male ratios in the general practice as a whole. The female to male ratios of all ages were consistently higher than among the total patient population under study. This strongly indicates that there are specific causes for the greater numbers of female benzodiazepine users in Dutch general practices. In our study the greater number of women receiving benzodiazepine prescriptions is not explained by overdiagnosis of benzodiazepine indications in women. Analysis of the indications recorded for benzodiazepines showed that most were simply requests for a first or repeat prescription. From the absence of sex differences in indications for repeat prescriptions we tentatively conclude that the diagnostic process leading to the continuation of benzodiazepine use does not explain the greater proportion of women prescribed these drugs.

General practitioners generally do not see patients when they request a prescription for benzodiazepines but see these patients when they have symptoms or disorders for which other treatments would be used. That diagnoses preceding a repeat prescription are mainly registered by the general practitioner's assistant suggests that general practitioners rarely re-evaluate their patients' continuing need for benzodiazepines. Dutch general practitioners often delegate requests for repeat prescriptions to assistants. ${ }^{24}$ This is especially worrying because half of all doctors' assistants in the Netherlands do not have the relevant training. ${ }^{24}$

Prescribing further benzodiazepines without reevaluating the patient may explain in part why this drug is prescribed excessively to men and women but does not explain the sex difference. It simply maintains the difference. We suggest that the sex difference among recipients of benzodiazepines originates from the time of the initial prescription.

In the age group 45-64 years significantly more men 


\section{Clinical implications}

- Benzodiazepines are prescribed for $10 \%$ of the population, of whom one third are long term users; only short term use has been shown to be effective

- Women use twice as much benzodiazepine as men, and its use increases with age

- Most prescriptions are repeats $(89 \%$ in this study) and are given by the doctor's assistant after requests $(70 \%)$ from pàtients

- More women are initially given benzodiazepines for conditions other than anxiety, stress, and insomnia

- Excessive prescribing of benzodiazepines might be reduced if they were no longer given for reasons other than anxiety, stress, and insomnia and requests for repeats were thoroughly evaluated by the general practitioner

than women had legitimate reasons for starting treatment with benzodiazepines. Doctors frequently diagnosed women with symptoms such as headache and general fatigue (not legitimate indications for benzodiazepines) as suffering from anxiety, stress or insomnia (which are legitimate indications) and thus as candidates for benzodiazepines. Even more striking was that the doctors also frequently diagnosed women as having headache for which subsequently benzodiazepines were prescribed. In addition, initial prescriptions in this age group were more often given to women than to men when neither symptoms nor diagnosis warranted the drug.

More research is needed to see if similar prescribing practices occur among general practitioners in other countries. In the Netherlands the sex difference in recipients of benzodiazepines is probably the result of a two step process. More women than men are initially prescribed benzodiazepines for conditions other than anxiety, stress, or insomnia. As benzodiazepines do not relieve other conditions, most patients asking for repeat prescriptions do so because they continue to have complaints. Subsequently general practitioners continue to prescribe benzodiazepines without fully reevaluating their patients' needs.

Three steps could be taken that might reduce the excessive prescribing of benzodiazepines to women. Strict criteria should be set for prescribing benzo- diazepines initially. Conditions other than anxiety, stress, and insomnia should be excluded as indications for the drug. And requests for repeat prescriptions of benzodiazepines should be thoroughly re-evaluated by the general practitioner.

We thank Jaap Goudsmit, Joke Haafkens, Claartje Moerman, Jan van Ree, and Bert Schadé for advice and critical reading of the manuscript.

1 Balter MB, Levine J, Mannheimer DI. Cross-national study of the extent of antianxiety/sedative drug use. $N$ Engl 7 Med 1974;290:769-7

2 Balter MB, Mannheimer DI, Mellinger GE, Uhlenhuth EH. A cross-nationa comparison of antianxiety/sedative drug use. Curr Med Res Opin 1984;8(suppl 4):5-20.

3 Herings RMC. Effecten van chronisch en gecombineerd geneesmiddlelengloruik. Utrecht: University of Utrecht, 1989.

4 Brekel EJG van den. Prescribed medicines 1981-1985. Maandberichten Gezondheidsstatistiek 1987:3:5-14.

5 Asselt JW van. Slaapverwekkend. Een onderzoek naar het gebruik van slaap-en kalmeringsmiddelen in Lelystad. Lelystad: GGD, 1989.

6 Central Bureau of Statistics. Vademecum gezondheidsstatistiek Nederland. The Hague: Staatsdrukkerij Uitgeverij, 1989.

7 Central Bureau of Statistics. Vademecum gezondheidsstatistiek Nederland. The Hague: Staatsdrukkerij Uitgeverij, 1993.

8 Mellinger GD, Balter MB, Uhelenhuth EH. Anti-anxiety agents: duration of use and characteristics of users in the USA. Curr Med Res Opi 1984;8(suppl 4):21-35.

9 Mellinger GD, Balter MB, Uhelenhuth EH. Prevalence and correlates of the long-term regular use of anxiolytics. $\mathcal{F} A M A$ 1984;251:375-9.

10 Catalan J, Gath DH, Bond A, Edmonds G, Martin P, Ennis J. Genera practice patients on long-term psychotropic drugs: a controlled investigation. Brf Psychiatry 1988;152:399-405.

11 Nolan L O'Malley K. Patients, prescribing and benzodiazepines. Eur f Clin Pharmacol 1988;35:225-9.

12 Rodrigo EK, King MB, Williams P. Health of long-term benzodiazepine users. $B M 7$ 1988.296:603-6.

13 Morgan K, Dallasso H, Ebrahim S, Arie T, Fentem PH. Prevalence, frequency and duration of hypnotic drug use among the elderly living a home. $B M 7$ 1988:296:601-2.

14 Woods $\mathrm{JH}$, Katz $\mathrm{JL}$, Winger G. Abuse liability of benzodiazepines. Pharmacol Rev 1987;4:251-413.

15 Institute of Medical Statistics. Diagnose informatie en medische statistie Slaapstoornissen, The Hague: Institute of Medical Statistics, 1989

16 Swinkels H. Huisarts en patient in cijfers. Enkele gegevens uit de Gezondheids enquete van het CBS. Huisarts Wet 1990;33:504-10.

17 Haafkens JA, Moerman C. Gender differencesin the use of benzodiazepines in Amsterdam. Contemporary Drug Problems 1992;Fall:505-32.

18 Timmermans AJGM, Dolmans JMEV, Bruinink RJ, van Ommeren GJ, van den Brink G. Benzodiazepinegebruik in Utrecht. Medical Contac 1983;38:1331-3.

9ost Flunitrazepam op de derde plaats. Pharm Weekbl 1988;123:522-5.

20 Bensing JM, Foets $M$, van der Velden J, van der Zee J. De nationale studie van ziekten en verrichtingen in de huisartsenpraktijk. Huisarts en Wetenschap 1991;34:51-61.

21 Lamberts $\mathrm{H}$, Wood M, eds. Intermational classification of primary care. Oxford: Oxford Unversity Press, 1987.

22 van der Velden J, Schellevis F, van der Steen J. International classification of primary care. Tabulaire lijst ten behoeve van de nationale studie van ziekten en verrichtingen in de huisartsenpraktijk. Utrecht: NIVEL, 1989.

23 Blijenberg-Ruis B, Garretsen HFL, Schuurman JH, Verdonk ALT. Het gebruik van slaap en kalmerende middelen. Een secundaire analyse van een Rotterdams onderzoek. T Soc Gezondheidszorg 1986;64:491-7.

24 Nijland A. De praktiikassistente in de huisartspraktijk. Progressie in professionalisering (dissertation). Groningen: Rijks Universiteit Groningen, 1991.

(Accepted 26 May 1993)

\section{A MEMORABLE PATIENT}

\section{Just a bullet in the heart}

He was in his mid-70s and had been admitted with a ruptured Achilles tendon. He had jumped down from a hedge on his farm, heard a loud crack, and thought he had broken his leg. His injury required a surgical repair. His preoperative chest $x$ ray examination showed an elongated opaque foreign body in the left cardiac area. Screening showed that this moved during cardiac contraction.

"Did you know," I said, "that you have a bullet in your heart?"

"Yes," said he, "it is a German 300 and it has been with me for 50 years. In fact," he continued, "I should have died on three occasions."

He had graduated from Aberystwyth University College in June 1914 and in August he joined the army and was posted to an infantry battalion. He was at the Western Front in October of that year and was out on patrol when he was shot in the chest. He thought then that he would die. He lay there for some time until a German patrol came across him. He remembered clearly a German soldier swearing at him and lifting his rifle to shoot him again, when mercifully a German officer appeared and with a pistol in his hand ordered the soldier to stop and to get a stretcher.

Some two weeks later he was in a German military hospital when the surgeon there, whom he thought was Sauerbruch, told him that he had a bullet in his heart and he proposed to remove it by open operation. Sauerbruch was one of the most eminent surgeons in the world, particularly in experimental surgery of the thorax. Nevertheless, our hero adamantly refused an operation. This was the third time, he thinks, he would have died

He recovered from his wounds and spent the rest of the war as a prisoner. Subsequently he had a distinguished career as a chief inspector of schools. On retirement he took up farming in south Pembrokeshire. When he died many years later he left his farms and his personal fortune to the University College of Wales, Aberystwyth.- $\mathrm{R} \mathrm{L}$ REES is a retired orthopaedic surgeon in Dyfed 